\title{
On the allocation of resources for secondary schools
}

Citation for published version (APA):

Haelermans, C., De Witte, K., \& Blank, J. L. T. (2012). On the allocation of resources for secondary schools. Economics of Education Review, 31(5), 575. https://doi.org/10.1016/j.econedurev.2012.02.007

Document status and date:

Published: 01/01/2012

DOI:

10.1016/j.econedurev.2012.02.007

Document Version:

Publisher's PDF, also known as Version of record

Document license:

Taverne

Please check the document version of this publication:

- A submitted manuscript is the version of the article upon submission and before peer-review. There can be important differences between the submitted version and the official published version of record.

People interested in the research are advised to contact the author for the final version of the publication, or visit the DOI to the publisher's website.

- The final author version and the galley proof are versions of the publication after peer review.

- The final published version features the final layout of the paper including the volume, issue and page numbers.

Link to publication

\footnotetext{
General rights rights.

- You may freely distribute the URL identifying the publication in the public portal. please follow below link for the End User Agreement:

www.umlib.nl/taverne-license

Take down policy

If you believe that this document breaches copyright please contact us at:

repository@maastrichtuniversity.nl

providing details and we will investigate your claim.
}

Copyright and moral rights for the publications made accessible in the public portal are retained by the authors and/or other copyright owners and it is a condition of accessing publications that users recognise and abide by the legal requirements associated with these

- Users may download and print one copy of any publication from the public portal for the purpose of private study or research.

- You may not further distribute the material or use it for any profit-making activity or commercial gain

If the publication is distributed under the terms of Article $25 \mathrm{fa}$ of the Dutch Copyright Act, indicated by the "Taverne" license above, 


\title{
On the allocation of resources for secondary schools
}

\author{
Carla Haelermans ${ }^{\mathrm{a}, \mathrm{b}, *}$, Kristof De Witte ${ }^{\mathrm{a}, \mathrm{c}}$, Jos L.T. Blank ${ }^{\mathrm{b}}$ \\ a Top Institute for Evidence Based Education Research, Maastricht University, The Netherlands \\ b Centre for Innovations and Public Sector Efficiency Studies, Delft University of Technology, The Netherlands \\ c Faculty of Business and Economics, KU Leuven, Belgium
}

\section{A R T I C L E I N F O}

\section{Article history:}

Received 5 September 2011

Received in revised form 20 February 2012

Accepted 27 February 2012

\section{JEL classification:}

I21

C33

D24

031

Keywords:

Secondary education

Productivity

Allocative efficiency

Output distance function

\begin{abstract}
A B S T R A C T
This paper studies the optimal allocation of resources - in terms of school management, teachers, supporting employees and materials - in secondary schools. We use a flexible budget constrained output distance function model to estimate both technical and allocative efficiency scores for 448 Dutch secondary schools between 2002 and 2007. The results indicate that the average technical efficiency amounts to about 78 percent, implying that, with the given resources, schools could improve students' educational performance by 28 percent. In terms of allocative efficiency, we estimate a 0.65 percent overutilization of teachers while management and supporting personnel are underutilized. The outcomes indicate that, despite the significant variation among schools, the average school is close to the optimal allocation of teachers.
\end{abstract}

(c) 2012 Elsevier Ltd. All rights reserved.

\section{Introduction}

Teacher shortage is a serious issue in both European countries (European Commission, 2006) and the United States (Cooley Nichols, Bicard, Bicard, \& Casey, 2008; Ingersoll \& Perda, 2010). For example, in the Netherlands, the expected shortage of teachers in secondary education for the next 10 years is about 500 full time equivalents (FTE) per year (Ministry of Education, 2011c). Fig. 1 presents the gap between the outflow and inflow of teachers. Similar patterns are detected for other European countries, like Germany and the UK (e.g., King, 2009; Lipsett, 2008; Santiago, 2002).

The increasing teacher shortage is due to four reasons. First, on the supply side of teachers: 'teaching' became less

\footnotetext{
* Corresponding author at: P.O. Box 616, 6200 MD Maastricht, The Netherlands.

E-mail address: Carla.Haelermans@maastrichtuniversity.nl (C. Haelermans).
}

attractive for youngsters as the jobs' social status diminished over time (Hargreaves et al., 2006, 2007). Second, teaching became a more 'female' occupation which is considered to combine easily with a family. Consequently, more teachers work part-time (e.g., 0.5 FTE) (Ministry of Education, 2011b). Third, the aging of the baby boomers (the cohort born after World War II) accelerates the outflow (Ministry of Education, 2011c). Fourth, at the demand side: an increasing attention to individual counseling and teaching (particularly for youngsters from low socio-economic status and for students with lower educational attainments) increased the demand for teachers (Ministry of Education, 2011c).

This paper analyzes whether alternative school resources, such as supporting personnel, school management and materials, can be - to a limited extend - substituted for teachers. In addition, it discusses the scope for performance improvements. Indeed, tightening budget constraints and increasing demands force schools to spend resources in terms of employees, management and material in the most productive way. Much is at stake. 


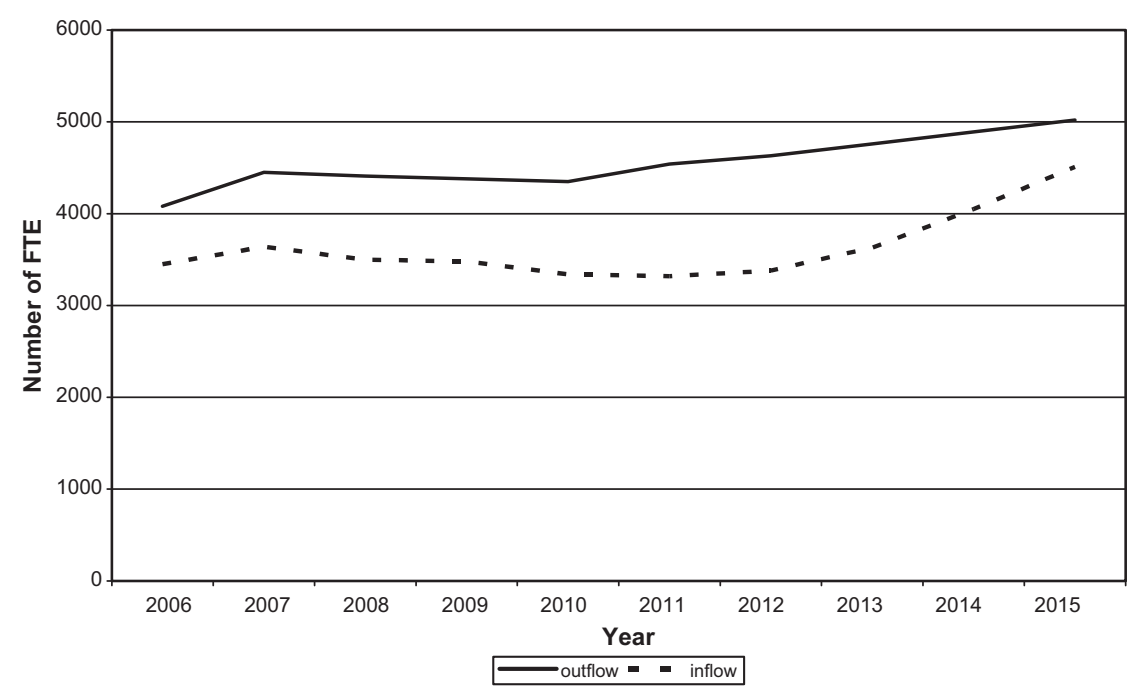

(Source of used data: CentER data/ECORYS/QQQ Delft, 2006)

Fig. 1. The predicted difference between inflow and outflow of teachers.

Source of used data: CentER data/ECORYS/QQQ Delft (2006).

The increasing requirements for schools (e.g., more pupil counseling, additional extra-curriculum activities, use of school buildings during weekends and summer holidays) induce pressure on the resources which are already in place. Productivity becomes an issue in schools (see Ball \& Goldman, 1997; Ministry of Education, 2011b, p. 98). With the insights at hand, resources can be reallocated among schools such that higher educational attainments can be obtained.

Although in policy documents the teacher shortage is referred to as an overall phenomenon (Ministry of Education, 2011c), it is of course clear that some subjects are more liable to a shortage of teachers than others (e.g., Ingersoll \& Perda, 2010; Mangrubang, 2005). We make abstraction of this heterogeneity for two reasons. First, our data include the total amount of teachers per school and do not allow us to make a distinction in the different teachers for the different subjects. Second, even if it were possible to make this distinction in the data, the amount of teachers per subject per school is very small, which makes the variation in the amount of teachers even smaller. The latter makes it impossible to study the teacher shortage per subject.

In line with previous literature (Fried, Lovell, \& Schmidt, 2008) performance is considered in two complementing ways: technical and allocative efficiency. The former denotes the relative ratio between the available resources and the outcomes. Relative to a production frontier, it measures the output shortfall of schools given the available resources. The latter enriches the technical efficiency estimations by price information. The measure of allocative efficiency yields insights in the under- or over-utilization of school resources. Allocative efficiency in secondary education has been largely overlooked. The available allocative efficiency studies mostly consider higher education (Cherchye \& Vanden Abeele, 2005; Johnes \& Johnes, 2009; Soares de Mello, Goncalves Gomes, Angulo Meza, Soares de Mello, \& Soares de Mello, 2006; Tauer, Fried, \& Fry, 2007). Some rare exceptions are Banker, Janakiraman, and Natarajan (2004) and Grosskopf, Hayes, Taylor, and Weber $(1997,2001)$ who both study school districts in Texas.

This paper examines performance in Dutch schools. Studying Dutch schools is attractive and insightful for three reasons. First, standardized performance measures of Dutch students make educational attainments well comparable. Second, there is information on student achievement, which compares the educational career of a student (both in terms of school track and retentions) with the education track predicted for a student at the end of primary education. Third, Dutch schools receive a yearly lump sum budget from the government, which is at the discretion of the school such that, within the existing legal framework, the allocation of this budget among the several resources is the decision of the school (Stb., 1963; 40). Therefore, a significant heterogeneity in hired resources, in terms of management, teachers, supporting personnel and material use, is observed. Note that the lump sum budget excludes (large and discontinuous) payments on housing infrastructure (the latter are provided by the municipal and central government).

Conceptually, we assume that schools are maximizing educational attainments under a budget constraint. From this starting point, one can derive an economic model which explains the performance and the optimal usage of resources. As we do not observe the relationship between inputs and outputs (Yatchew, 1998), we rely on semi-parametric models which avoid a specification bias. In particular, technical and allocative efficiency are estimated against a frontier consisting of best practice observations. We examine the potential increase in educational attainments under budget constraints. Formally, this corresponds to a so-called budget restricted indirect output distance function (IOD) model (Blank, 2009; Grosskopf et al., 1997). 
The paper contributes to the literature at three points. First, from a methodological point of view, the paper provides an empirical application of a budget restricted IOD function by estimating allocative efficiency of schools under a flexible Fourier functional form. Previous literature did never use the Fourier specification to estimate allocative efficiency scores. Nevertheless, it is convenient as it imposes little structure on the underlying data. Given that the relationship between inputs and outputs is unknown, it avoids the specification bias.

Second, from an empirical point of view, the paper relies on a rich and European dataset. Allocative efficiency has only occasionally been studied in European countries. Nevertheless, the European education system significantly differs from the American system such that the conclusions cannot easily be transferred. For example, this paper considers the school as the appropriate level of analysis, and not the district. The school level is interesting and applicable to many European countries, whereas school districts are mainly an American approach. By analyzing allocative efficiency in Dutch schools, which has been argued to be interesting to study, this paper fills the gap.

Third, the results are insightful to education policymakers as they provide an indication on the efficiency of schools and the misallocation of resources. Tightening budget constraints force government to spend public money as efficient and effective as possible. The results can be used to reallocate resources in a more efficient and effective way.

The remainder of the paper is structured as follows: Section 2 described the Dutch secondary education system. Section 3 outlines the methodology and the model. Section 4 describes that data and data sources while Section 5 discusses the results. Some concluding remarks and a discussion are presented in Section 6.

\section{Dutch secondary education}

Dutch secondary education offers five different instruction levels. Students enter a level of education based on a national standardized test and a recommendation from their elementary school. The first three years of secondary education are called lower secondary education. The last years of secondary education (the total number of years in secondary education depends on the level of education) are called upper secondary education. Each of the education levels is concluded with a standardized national examination in the final year. The five different levels of secondary education are as follows (Dutch abbreviations in brackets) ${ }^{1}$ :

- practical education (PRO, four years);

- practical prevocational school (VMBO-bk, four years);

- theoretical prevocational school (VMBO-gt, four years);

- higher general school education (HAVO, five years);

- pre-academic education (VWO, six years).

\footnotetext{
${ }^{1}$ Eurydice is used for the terminology (Executive Agency of Education Audiovisual and Culture, 2009a, 2009b).
}

Most schools offer a combination of these levels of education. In VMBO, a distinction is made between a theoretical (VMBO-gt) and a practical (VMBO-bk) course of study. This thesis distinguishes eight types of schools, ranging from schools offering solely PRO, VMBO or VWO to the comprehensive schools that offer all levels of education.

Secondary schools in the Netherlands receive a lumpsum payment from the government every year. Within the existing legal framework, the allocation of this budget among the several resources is the decision of the school. Note that the lump-sum budget excludes (large and discontinuous) payments for housing infrastructure (the latter are provided by the municipal and central government). In most cases, the municipality is responsible for providing the accommodation of the school. However, the school itself is responsible for the maintenance of the building. In practice, this means that the school is granted a certain amount of finance from the municipality to fulfil this responsibility. Building new accommodation often only happens when the number of students has risen substantially in the previous years and is solely based on the number of students.

Apart from the lump sum, there are no other sources of revenues that schools can use and that may affect factor substitution decision. Schools are allowed to ask for a voluntary parental contribution, but this contribution can only be used in the benefit of the student (e.g., for school trips).

Until recently there was little variation in teacher salaries and there were mainly two teacher salary scales for teachers in primary education, secondary education and vocational education. These were called teacher salary scale A (ranging from 2120 to 3058 euro per month in 2004) and teacher salary scale B (ranging from 2198 to 3359 euro per month in 2004) (Ministry of Education, 2005). After 2006 this changed and two extra teacher salary scales were introduced in secondary education, teacher salary scale $C$ and teacher salary scale $D$, and extra possibilities to reward teachers (Ministry of Education, 2011a). However, our data only ranges until one school year after the change and the main changes in schools due to this change only happened from the year after that. Therefore, during the years that we have data for, there are hardly any options to vary in teacher salaries, except due to age.

There is no supplement salary and therefore schools do not really have any options to attracted better teachers. Schools do have the discretion to hire and fire their personnel, however, most teachers, administrators and managers have a permanent contract and can therefore not be fired easily. So in the short run, there is not much schools can do. In the long run, they could use the turnover of people that retire to change their personnel population.

The accountability system of schools in the Netherlands is executed by the Education Inspectorate. At first, this system is based on the performance of students. Students write a national exam for each subject in graduation year. These exams are standardized and objectively graded. Furthermore, performance of students is monitored by student achievement. Student achievement gives information on the educational track of a student in a given year with the education track predicted for a student at the end of 
primary education and on repetition. If performance on national examinations and student achievement are as they should be, the Education Inspectorate visits schools once every three years for an inspection. If these numbers are not as they should be, schools are visited every year. If the school does not perform accordingly for a few years in a row, the inspection is accentuated and a plan of change is written by the school (in cooperation with the Education Inspectorate). The education inspectorate will only interfere in the finances of the school (and spending pattern) if such a plan has to be written.

\section{Methodology}

\subsection{Performance estimation}

We start from the presumption that schools, with an exogenous budget, are maximizing the educational attainments of students. In a sense, schools are trying to become best practices in educating students, and, thus, to reach the frontier of the production function with their budget. The best practice frontier can be determined along various ways (see Fried et al., 2008 for a discussion). Three streams of literature can be distinguished. First, the fully non-parametric Data Envelopment Analysis (DEA; Charnes, Cooper, \& Rhodes, 1978) does not assume any a priori specification on the production function. It is computed using linear programming techniques. As a disadvantage, the traditional models do not allow for statistical inference, measurement errors and noise in the data. Although the robust order-m method of Cazals, Florens, and Simar (2002) accounts for the former two drawbacks, the technique can up-to-now not properly deal with statistical noise.

Second, the semi-parametric Stochastic Frontier Model (SFA; Aigner, Lovell, \& Schmidt, 1977; Meeusen \& Van den Broeck, 1977) explicitly exploits the noise in the data. It is a semi-parametric technique which decomposes the error term $\varepsilon$ into two terms: $\varepsilon=v-\mu$. The term $v$ denotes a random component which captures the stochastic elements and unobserved heterogeneity. $v$ is assumed to be distributed along $N\left(0, \sigma_{v}\right)$. The term $\mu$ represents an inefficiency term and captures the shortfall in output given the inputs. As efficiency should be positive, $\mu$ is assumed to be half-normal distributed: $\mu \sim\left|N\left(0, \sigma_{\mu}\right)\right|$ (see Kumbhakar and Lovell (2003) for an extensive discussion). As a disadvantage, the method does not allow for budget constraints.

A third methodology, which is advocated in this paper, relies on Corrected Ordinary Least Squares (COLS). This methodology is convenient as it easily allows for the estimation of fixed effects (as does SFA, or alternative parametric techniques), but can also include budget constraints.

Corrected Ordinary Least Squares (COLS) method is a rather strict method in which the OLS regression is shifted to the observation(s) with the most favorable ratio of outputs to inputs. ${ }^{2}$ The(se) observations are considered as best practices and obtain an efficiency score $\lambda$ equal to 100 .

\footnotetext{
2 The strict assumption on efficiency is convenient in the setting at hand as it provides a lower bound on the efficiency estimations. In other words, by no other assumption, inefficiency will be higher.
}

Inefficient observations lie below this best practice frontier and obtain an efficiency score $\lambda$ smaller than 100 . The score $(1-(100 / \lambda))$ can be interpreted as the percentage output increase if the observation would perform as efficient as its best practice. If in the efficiency estimation the observation is further constrained by the total cost of inputs, a so-called indirect output distance (IOD) function is estimated (for a detailed discussion, see Färe \& Primont, 1995).

We apply an IOD function which is similar to the model of Grosskopf et al. (1997). Schools are producing multiple outputs (see below) under budget constraints, which can be thought of as exogenous to the schools. The deterministic model can be written in short hand as follows (note that the full budget restricted output distance function including the full share equations, is presented in Appendix A):

$\ln (\mathrm{IOD})=f\left(\ln y, \ln \left(\frac{w}{C}\right), \ln z\right)$

where IOD stands for the indirect output distance function with an a priori determined functional form denoted by $f$ (e.g., Cobb-Douglas, Translog, Fourier), $y$ is the vector of outputs, $w$ denotes the vector of prices of the used resources, $C$ is the vector of costs and $z$ is a vector capturing fixed inputs or school characteristics (reflecting observed and unobserved heterogeneity). Several (mild) properties, required for a meaningful estimation, hold for the model. As expected, the model is non-decreasing and quasi-concave in $w / C$ (see, e.g., Coelli, Rao, O’Donnell, \& Battese, 2005; Färe \& Primont, 1995). Conditional independence (cf. a separability condition) is imposed to the model in that information on one input does not yield information on other inputs.

The costs shares are immediately derived from the IOD by Roy's identity, in particular, as the first derivative with respect to costs (see Färe \& Primont, 1995, p. 92). They correspond to:

$S_{i}=\frac{[\delta \ln \operatorname{IOD}(y,(w / C), z)] /\left[\delta \ln \left(w_{i} / C\right)\right]}{\sum_{n}[\delta \ln \operatorname{IOD}(y,(w / C), z)] /\left[\delta \ln \left(w_{n} / C\right)\right]}$

Including costs shares (and thus estimating an IOD function instead of an output distance function) is convenient as it allows us to estimate the optimal amount of different types of costs (e.g., personnel costs, management costs, supporting personnel and material use). The comparison between the actual costs and the optimal costs yields allocative efficiency scores. ${ }^{3}$

The indirect output distance function and the cost share equations provide a set of equations from which the parameters can be estimated. In practice, the system of equations is estimated by system OLS. ${ }^{4}$ Intuitively, this corresponds to a least squares estimation with multivariate

\footnotetext{
3 From a practical perspective, an additional advantage of including cost shares is that the estimations are more efficient as more information is added to the model (Blank, 2010; Greene, 2008; Grosskopf et al., 1997).

4 This leads to similar results compared to using SUR as estimation method.
} 
regression systems under a joint density. ${ }^{5}$ To foster further applications, the TSP code is available upon request.

\subsection{Model specification}

As typical in (semi-)parametric analysis, Eq. (1) requires an a priori specification of the production function $f$. A survey by Yatchew (1998) clearly indicates that economic theory hardly ever provides a precise specification of the functional form of production functions. This has recently been confirmed for educational settings by Rothstein (2010). To avoid a specification bias and to allow for some flexible model characteristics it seems appropriate to test the choice of the functional form. Therefore, we start from estimating a Cobb-Douglas production function, and systematically add interaction terms such that we estimate a Translog and Fourier specification. The Fourier cost function adds sine ( $\sin$ ) and cosine (cos) terms to the Translog model, which in turn adds quadratic terms to the Cobb-Douglas (CD) specification. The Fourier cost function does not only allow for linear relationships as in CD and non-linear causalities as in Translog, but for almost infinitely flexible relationships. The Fourier specification is thus a generalization of these models. A large advantage of the Fourier function is that it is essentially unbiased and obtains accurate finite parameter approximations (Gallant, 1981; and see Gallant, 1984 for visual representations). ${ }^{6}$ While $C D$ and Translog specifications only exploit the dominating trend in the data, and thus provide only a local approximation for the unknown function, the Fourier model estimates a global alternative as it exploits the variability over the whole range of data. In fact, the Fourier specification provides a framework to estimate a parametric function with a flexibility comparable to a nonparametric approach (Gallant, 1981, 1984; Kuenzle, 2005). Because the production function is not a periodic function, we have to rescale all values such that they lie between 0 and $2 \pi$. It is possible to include several grades (denoted by $N$ ) in the Fourier function. $N$ denotes the number of sine and cosine terms included. $N$ is determined statistically. The grade of the goniometric terms is established by testing on the basis of an $f$ whether the sum of squared residuals (SSR) differs significantly between two values of $N$. As such, it tries to capture the true relationship between costs, and inputs and outputs. For instance, testing whether the SSR for $N=0$ and $N=1$ differs significantly, reveals whether a Fourier function of grade 1 , which includes $\sin (w / C), \cos (w / C), \sin (y), \cos (y), \sin (z)$ and $\cos (z)$, is statistically preferred to a function of grade 0 , i.e. a Translog model. Comparing $N=1$ and $N=2$ makes clear whether a Fourier function of grade 2, which includes $\sin (w / C)$, $\sin (2 w / C), \cos (w / C)$ and $\cos (2 w / C), \sin (2 y), \sin (2 y), \cos (y)$ and $\cos (2 y)$, etc., is preferred to a Fourier of grade 1 . We start from the Cobb-Douglas specification and gradually

\footnotetext{
5 Note that one share equation in the output distance function model has to be dropped because the shares add up to one causing the variancecovariance matrix of the error terms to be singular.

6 This has also been tested using Monte Carlo Simulations (Chalfant \& Gallant, 1985).
}

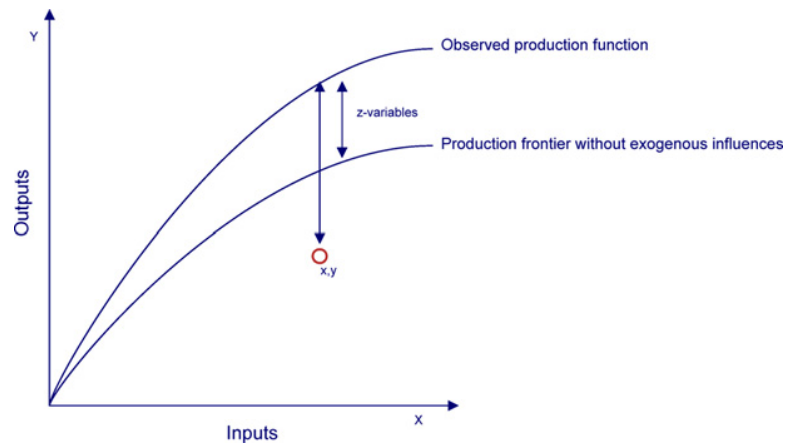

Fig. 2. The production frontier with and without environmental variables.

test the robustness of the results by different specifications. The results (see below) point out that the Fourier specification of grade 1 should be preferred in the setting at hand. This specification is included in Appendix A.

\subsection{Observed and unobserved heterogeneity}

Observed heterogeneity is captured by including exogenous characteristics in the model (denoted by $z$ ). The exogenous characteristics cannot be influenced by policy or school management and these variables are directly included in the output distance function and share equations as the $z$-variables. Including or excluding exogenous characteristics influences the position of the frontier such that they have to be taken into account in determining the optimal composition of resources and student attainment. This is graphically presented in Fig. 2.

To capture unobserved heterogeneity, we exploit the panel data structure of the data by including school type, year and region fixed effects in the estimation. We observe 9 different school types (ranging from pre-vocational education till pre-university education), 6 years, and 4 regions. Region fixed effects are included as school inspectorate argues the large dispersion in school attainments across regions (Inspectie van het Onderwijs, 2011). The fixed effects are estimated for the output distance function but not for the share equations (as the share equations are a derivative of the output distance function with respect to $(w / C)$, and the fixed effects do not appear in the output distance function as an interaction term with $(w / C))$.

\section{Data and model specification}

\subsection{The data}

To estimate the technical and allocative efficiency of schools, we apply the semi-parametric IOD model to a representative balanced panel dataset of 448 Dutch secondary schools covering the school years 2002/03 to 2007/08. For convenience the school year 2002/03 is referred to as 2002, and so on. The data are obtained from several existing administrative data sets from the Ministry of Education, the Education Inspectorate and Statistics Netherlands. 
Table 1

Summary statistics (for 2007).

\begin{tabular}{|c|c|c|c|c|}
\hline & Mean & Standard deviation & Minimum & Maximum \\
\hline Central examination grade & 6.4 & 0.2 & 5.4 & 7.2 \\
\hline Student achievement & 0.832 & 0.061 & 0.571 & 1.067 \\
\hline Number of FTE management personnel & 9 & 7 & 1 & 44 \\
\hline Number of FTE teaching personnel & 131 & 80 & 15 & 468 \\
\hline Number of FTE supporting personnel & 23 & 16 & 3 & 119 \\
\hline Total FTE & 163 & 97 & 19 & 616 \\
\hline Total costs (in 1000 euro) & 12,311 & 7944 & 1078 & 51,481 \\
\hline Management personnel costs per FTE (in euro) & 88,806 & 28,465 & 19,375 & 231,925 \\
\hline Teaching personnel costs per FTE (in euro) & 67,528 & 16,086 & 38,581 & 155,061 \\
\hline Supporting personnel costs per FTE (in euro) & 21,239 & 7939 & 10,406 & 93,087 \\
\hline Competition & 0.23 & 0.23 & 0.02 & 2.89 \\
\hline Number of schools per governing body & 5.57 & 7.57 & 1 & 31 \\
\hline Share of students from a disadvantaged neighborhood & 0.027 & 0.030 & 0 & 0.197 \\
\hline Degree of urbanization & 0.504 & 0.319 & 0.010 & 0.969 \\
\hline Total number of students per school & 1744 & 991 & 158 & 5971 \\
\hline Average years of experience managers & 17.0 & 5.1 & 0.2 & 30.8 \\
\hline Average years of experience teachers & 12.0 & 2.4 & 1.3 & 18.9 \\
\hline Percentage part time teachers & 0.26 & 0.08 & 0.09 & 0.54 \\
\hline Number of locations per school & 2.1 & 1.5 & 1 & 10 \\
\hline
\end{tabular}

\subsection{Production}

Educational production is commonly defined as some kind of measure of educational attainments in knowledge and skills (Wenger, 2000). We use two measures for educational production: the average student central examination grades per school and the average student achievement each year during secondary education. ${ }^{7}$ The former serves as a proxy for attainments, while the latter for quality.

With respect to the first, every graduating student undertakes this test at the end of secondary education for the subjects the student is registered. The exams are graded in a double blind way and the school and the teacher of the students cannot directly influence the outcome of the exams. ${ }^{8}$ The average grade per school is based on the average of all central examination grades for all students in all subjects. Note that the level of analysis is the school and not the subject or the student. Our results will therefore not make a conclusion on teacher shortage in individual subjects.

To proxy the quality of the educational process, we include a composite number of Education Inspectorate: average aggregated corrected achievement. This number compares the educational track of a student in a given year with the education track predicted for a student at the end of primary education. An aggregated corrected achievement of 1 denotes that all students are exactly in the year and level of education they are predicted to be according to primary education test results. Both output measures are multiplied by the total number of students, as more expenses should either lead to higher performance of the current number of students or the same performance for

\footnotetext{
7 A robustness check with only central examination grades as output and number students and student achievement as control variables yields very similar results.

8 School might be able to indirectly influence exam results on an abstract level as they may, for example, be teaching to the test. However, as the exams are nationally developed and cannot directly be influenced by the school, we assume independence of these results.
}

a higher number of students. Summary statistics are provided in Table 1.

Table 1 shows that the average central examination grade amounts to 6.4 on a 10 point scale. A 5.5 is sufficient to pass the subject. The grades range from 5.4 to 7.2. Despite the larger variation, the standard error is relatively low. Student achievement has an average of 0.832 and the total number of students is on average 1744 per school.

\subsection{Resources}

School resources are summarized along four relatively homogeneous categories: (1) management personnel, (2) teaching personnel, (3) supporting personnel and (4) material supplies. Capital in the sense of housing infrastructure is not accounted for due to reasons explained in the section on Dutch secondary education. For the human resources (the first three groups), data are available on full time equivalents (FTE) and costs. In particular, the costs correspond to the costs per FTE per year. The total average number of FTE per school equals 163, consisting for $80 \%$ out of teachers, $14 \%$ of supporting personnel and the remaining $6 \%$ of managing personnel. The total costs of a school are about 12 million euro per year. The majority of the costs are spend on teaching personnel, followed by materials, managing personnel and, finally, supporting personnel. Besides teaching, a teacher has some management and administrative duties. The different tasks within one function are not officially reported. We assume that there is a homogeneous distribution of these different tasks within one function, both between teachers within one school and across schools.

The wage of teachers, school management and supporting personnel is, a priori, similar for all schools in the Netherlands, as a teacher with a given experience and a certain age would earn a similar wage across all schools. Therefore, we expect prices to be comparable and use the reported expenses spend on the different personnel types per school. For the price of materials the consumer price index provided by Statistics Netherlands is used as a proxy. 
Table 2

Technical efficiency scores of Dutch secondary schools 2002-2007 in percentages (Model: Fourier grade 1).

\begin{tabular}{|c|c|c|c|c|c|c|c|}
\hline & 2002 & 2003 & 2004 & 2005 & 2006 & 2007 & 2007 Translog \\
\hline Average & 88.44 & 81.68 & 91.29 & 83.33 & 77.15 & 77.40 & 67.02 \\
\hline Standard deviation & 2.59 & 2.22 & 2.29 & 3.38 & 4.41 & 4.64 & 7.77 \\
\hline Minimum & 72.91 & 67.06 & 78.43 & 71.40 & 67.69 & 65.53 & 40.41 \\
\hline 2nd quartile & 87.37 & 80.71 & 90.15 & 81.67 & 74.97 & 75.00 & 63.30 \\
\hline Median & 88.47 & 81.72 & 91.37 & 82.83 & 76.25 & 76.45 & 67.72 \\
\hline 4th quartile & 89.79 & 82.93 & 92.68 & 84.01 & 77.57 & 78.46 & 72.01 \\
\hline Maximum & 100.00 & 100.00 & 100.00 & 100.00 & 100.00 & 100.00 & 100.00 \\
\hline
\end{tabular}

As we use school years whereas the price index is measured in calendar years, we have to recalculate the value of the price index to fit our school year data. Consumer prices only differ by year, and not by geographical region.

\subsection{Control variables (z-variables)}

Some influences are exogenous to the school and create heterogeneity across schools. These variables include the number of schools per governing body, the degree of competition, the share of students from a disadvantaged neighborhood, degree of urbanization, management and teacher experience and the number of locations per school.

The latter reflects the geographical spread of a school over different sites. This might lead, on the one hand, to additional costs due to extra travel time (for teachers), or on the other hand, to scale economies (e.g., in management). All these variables influence the efficiency of a school but cannot be influenced by the school management. The number of schools per governing body may, on the one hand, reflect scale economies thanks to participation in a schools' network and shared services; on the other hand, it captures the harms of a centralized bureaucracy. The average number of schools per governing body is almost 6 with a minimum of 1 and a maximum of 31 . The latter is one specific governing body which manages many schools.

Previous research has shown that competition fosters productivity (Abbott \& Doucouliagos, 2009; Millimet \& Collier, 2008) and that urbanization is related to productivity (Naper, 2010). Competition is estimated as the number of secondary schools per 10,000 inhabitants in a municipality and has an average value of 0.23 . The competition variable thus only includes secondary schools. In the short run, it is unlikely that efficiency affects the level of competition (and thus creating a source of endogeneity) as rules and regulations on the entrance of new schools, closure of schools and mergers are very strict. Furthermore, we see only few changes in the competition index in our data.

The share of students from a disadvantaged neighborhood amounts, on average, to $2.7 \%$.

We observe that the number of locations per school is, on average, 2 although it ranges from 1 to 10 . The locations are mostly located within one city. Having more than one location is often due to mergers between schools. Furthermore, it might have a historical reason. If schools are growing in terms of student population, municipalities, which are responsible for capital, were often reluctant to built new (and bigger) schools. Therefore, the existing locations were kept and better used by separating students from a different track into different locations, or separate lower secondary education from upper secondary education. The distance between sites does influence the costs but is also accounted for in the lump sum. Therefore, the financial effect cancels out.

We observe managers with an average experience of 17 years. The average experience of teachers is 12 years, while the average amount of part time teachers is $26 \%$. These three variables (experience of managers and teachers and the share of part time workers) are fixed in the short run, as schools cannot suddenly change their whole staff.

\section{Results}

Before estimating the results, we attempt to reveal the functional form of the IOD function by examining the grade of the Fourier function. We estimate the following model options: the Cobb-Douglas (result: degree of freedom $(\mathrm{df})=14$, $\log$ likelihood $(\log l)=20,601)$, Translog $(\mathrm{df}=115, \log l=21,083)$, Translog Fourier grade $1(\mathrm{df}=141$, $\log l=23,705)$ and Translog Fourier grade $2(\mathrm{df}=167$, $\log l=23,820$, not converging). The $\log$ likelihood scores and the convergence information indicate that the Translog Fourier model of grade 1 is the best model.

The remainder of the paper applies a Translog Fourier function of grade 1 (i.e., including $\sin (w / C)$ and $\cos (w / C)$, $\sin (y)$ and $\cos (y), \sin (z)$ and $\cos (z))$ as functional form.

The full estimation results are available upon request from the corresponding author. ${ }^{9}$ About half of the parameters are significant at the 5 percent level, the $r$-squares of the cost shares are reasonable and all cost variables have a positive coefficient. The latter indicates that the monotonicity condition is satisfied. The concavity condition, tested for the Translog part of the model, is also satisfied as almost all elasticity's of substitution are negative and the Hessian is negative definite. ${ }^{10}$

\subsection{Technical efficiency}

Table 2 presents the average technical efficiency scores for Dutch secondary schools for 2002-2007. This table also includes the results for the Translog function for 2007, to show the robustness of the results. However, because of similarity of the results and for the sake of space we will

\footnotetext{
${ }^{9}$ Although the statistical analysis points out that the Fourier function of grade 1 is the preferred functional form, a robustness test with CobbDouglas and Translog specification delivered comparable results. This points to robust results. The results of the Translog specification are also included in the full estimation results, which are available upon request. 10 The Hessian has been evaluated for every observation separately.
} 
Table 3

Allocative efficiency in percentages (data for 2007).

\begin{tabular}{|c|c|c|c|c|c|c|c|}
\hline & Average & $\begin{array}{l}\text { Standard } \\
\text { deviation }\end{array}$ & Minimum & $\begin{array}{l}\text { First } \\
\text { quartile }\end{array}$ & Median & $\begin{array}{l}\text { Third } \\
\text { quartile }\end{array}$ & Maximum \\
\hline Deviation from optimal share - management & -0.01 & 2.75 & -7.51 & -1.88 & -0.62 & 1.57 & 18.61 \\
\hline Deviation from optimal share - teaching personnel & 0.29 & 4.93 & -16.59 & -2.86 & 0.65 & 3.48 & 13.61 \\
\hline Deviation from optimal share - supporting personnel & $-0.88^{* * *}$ & 1.42 & -3.96 & -1.85 & -0.97 & -0.02 & 6.02 \\
\hline Deviation from optimal share - material & $0.60^{* * *}$ & 4.63 & -12.57 & -2.13 & 0.44 & 3.22 & 16.64 \\
\hline
\end{tabular}

S*** Significantly different from zero at $1 \%$ level.

first start discussing the results for 2007. Note that in our setting, by construction, efficiency ('doing things right') is closely related to effectiveness ('doing the right things'). Indeed, our output variable corresponds to average pupil test scores and average student achievement. Therefore, in most cases the most efficient school also has a high average central examination grade. ${ }^{11}$ With respect to efficiency, a deviation $(\lambda)$ from 100 denotes that the school can improve its output by $(1-(100 / \lambda))$ percent if it would use its given resources as efficient as its best practice in 2007. The average technical efficiency score for the 448 schools is $78 \%$, implying that with the same resources they could improve educational performance by about $28 \% .75 \%$ of the schools could improve the educational attainments of the students by 25 percentage point (note that this is controlled for observed heterogeneity among schools, as well as resources; see before). ${ }^{12}$ We observe a minimum efficiency score of $66 \%$ which indicates that the least performing Dutch school could improve the educational attainments of its students by more than $30 \%$ if the school would use its resources as efficient as its best practice. The standard deviation of the scores amount to $4.6 \%$, which indicates that, on average, Dutch secondary schools are well comparable and do not differ much in terms of efficiency.

The results for other years are similar to the outcomes for 2007. For 2006, the lowest average efficiency score is observed. This could be due to the large variance in student achievement in 2006. Moreover, in 2006 there was a relative large jump in costs, compared to the years before and the years after. To our best knowledge, there is no evident explanation for the latter two deviations. The highest average efficiency is observed in 2004. In this year, schools could improve their performance by about $9 \%$ if they would perform as efficient as the best in class. Lastly, Table 2 shows that the results for the Translog model specification are not that different from the Fourier grade 1 specification, in 2007.

\subsection{Allocative efficiency}

While technical efficiency does not account for prices and costs, allocative efficiency scores do. Although all schools observe the same exogenous prices, a priori, it can be expected that not all schools use the optimal input mix. In this case, higher output can be obtained by re-allocating

\footnotetext{
11 Although this does not necessarily need to hold.

12 Running the analysis without fixed effects shows that the relatively high efficiency scores are not related to the inclusion of the fixed effects.
}

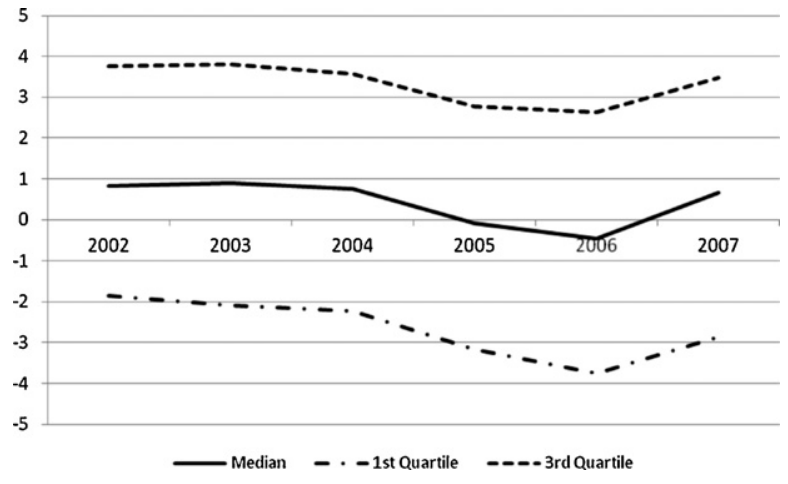

Fig. 3. Over/underutilization of teachers (in \%).

the inputs. As schools differ on resources, student population, location, etc., the optimal input mix will be different for every school.

Allocative efficiency is the difference in the actual value of the cost share of a resource compared with the optimized cost share equation of that resource, which is estimated simultaneously with the indirect-output distance function and the other cost shares.

The results are presented in Tables 3 and 4. A positive sign denotes an overutilization of the input (i.e., allocative efficiency could be improved by diminishing this variable), while a negative sign indicates underutilization of the input. On average, the share of management and supporting personnel is lower than the optimum. On the other hand, schools use more teachers and material than would be optimal. The deviation from the optimum for material and supporting personnel is significantly different from zero at the $1 \%$ level. The deviation from the optimum for management and teaching personnel are not significant, not even at the $5 \%$ level. In the following description and interpretation of the results we focus on the results of the median in 2007. ${ }^{13}$

From Table 3, we observe an average overutilization of teachers of $0.65 \%$. This average hides a significant dispersion across the distribution. The latter is also visible in Fig. 3. As the average school hires 131 FTE teachers, an overutilization of $0.65 \%$ indicates that the same or higher test scores could be reached with 130 FTE teachers. It is interesting to note that the $0.65 \%$ overutilization in FTE in 2007 amounts to about 400 FTE on a total of 64,000 FTE (Ministry of Education, 2011b), which is almost one half

\footnotetext{
${ }^{13}$ Results for the other years are available upon request from the corresponding author. They are not included in the paper to reduce its length.
} 
Table 4

Median of allocative efficiency 2002-2007 in percentages. ${ }^{a}$

\begin{tabular}{|c|c|c|c|c|c|c|c|}
\hline & 2002 & 2003 & 2004 & 2005 & 2006 & 2007 & 2007 Translog \\
\hline Deviation from optimal share - management & -0.13 & -0.06 & -0.25 & -0.50 & -0.68 & -0.62 & -0.64 \\
\hline Deviation from optimal share - teaching personnel & 0.81 & 0.89 & 0.75 & -0.09 & -0.47 & 0.65 & 0.38 \\
\hline Deviation from optimal share - supporting personnel & -0.14 & 0.06 & 0.21 & 0.21 & 0.23 & -0.97 & -0.10 \\
\hline Deviation from optimal share - material & -1.03 & -1.31 & -1.22 & -0.25 & 0.44 & 0.44 & 0.31 \\
\hline
\end{tabular}

a Other output for all years as presented in Table 3 is available upon request.

of the teacher gap in 2007 that has been predicted in the report of CentER data, ECORYS and QQQ Delft (2006). In the latter report, the teacher shortage in 2007 is estimated on about 1000 on a total of almost 62,000 FTE (1.6\%). ${ }^{14}$ This might indicate that, for some schools, part of the predicted teacher shortage could be tackled by better allocation of resources. However, the average school operates close to the optimum with respect to the number of teachers.

Furthermore, there is an underutilization of $0.61 \%$ of managers. This denotes that the median school could increase its management structure from 9 FTE managers to 9.1 FTE. This small average underutilization hides a significant dispersion across the distribution. While the median school has an underutilization of management, the top $25 \%$ of schools have a (large) overutilization. These correspond to the larger schools compared with the total sample. Although previous research indicates a sufficient number of managers at Dutch secondary schools (Blank, Koot, \& van Hulst, 2007), our results show that many schools have either an underutilization (bottom $50 \%$ ) or overutilization (top $25 \%$ ) of managers. This mismatch can be explained by the constant warning for an upcoming shortage, not only for teachers but also for managers (CentER data/ECORYS/QQQ Delft, 2006). This has been confirmed by sector organizations (Sectorbestuur Onderwijsarbeidsmarkt, 2009; Van Velden, 2002). Another reason might be the increasing number of the so-called 'middle' managers and organizational units (Odenthal, Poelmann, van der Ven, \& van der Weide, 2007; Simkins, 2000).

Interestingly, schools have $0.97 \%$ too few supporting personnel than would be optimal, and $0.44 \%$ too much material than would be optimal. The underutilization of supporting personnel is rather surprising given its low costs and given its effectiveness (e.g., Groom \& Rose, 2005).

From Table 4 we see that the results for the Translog model specification are not that different from the Fourier grade 1 specification, in 2007.

Despite the critical teacher shortage, it is interesting to observe that some schools use too many teachers and too little of the other resources. At one end, there is a school which should hire $16.6 \%$ more teachers (i.e., from 70 FTE to 80 FTE) to improve the educational attainments of its students. At the other end, a school hires $13.6 \%$ too many teachers. Also, the median school hires too many teachers, although schools are very close to the optimum. It seems that the teacher shortage in the Netherlands may be decreased by reallocating teachers across schools and/or

\footnotetext{
14 This situation was predicted for an economic recession, which was the case in 2007.
}

by relying on alternative resources. Not all tasks in a school have to be fullfilled by teachers. For example, supervision of a group of students in self-study, the support and coaching of student projects or supervision during lunch time can be undertaken by supporting personnel (see e.g., Blatchford \& Sumpner, 1998).

\subsection{Trends in allocative efficiency}

The inter-temporal trends in resource utilization allow us to explore the under and overutilization over time. Teacher shortage is already an issue for some time (e.g., CentER data/ECORYS/QQQ Delft, 2006; Municipality of Amsterdam, 2003; Nelis, 2004; Stijnen, 2003). Nevertheless, we observe in Fig. 3 that the median school in the sample has an overutilization of teachers between 2002 and 2004. In those years, a better allocation of teachers over schools could have decreased the teacher shortage for the bottom quartile of schools. Also in this inter-temporal perspective, the numbers are on a similar level as the predictions made by CentER data, ECORYS and QQQ Delft (2006). Furthermore, the resulting numbers from our study are on the same level as the numbers from the report of the Ministry of Education (2011c), in which a yearly shortage of about 500 FTE was predicted. Only between 2005 and 2006 a median underutilization emerged, which is altered in 2007. A possible reason for this sudden change in trend could be that schools and municipalities anticipated on the teacher shortage, as this was already an issue for a longer time (Municipality of Amsterdam, 2003).

\subsection{Control variables in the model}

The estimation results of the exogenous variables are presented in Table 5 . They indicate the correlation between the control variables and educational performance or cost shares. In the IOD model, a positive (negative) sign indicates an unfavorable (favorable) influence on performance.

For presentational reasons, Table 5 only presents the coefficients of the main effect (without interactions). It should be noted that the Fourier model includes several interaction terms of these control variables (with each other, with outputs, and with costs). However, on average (i.e., multiplying the mean values of the variables with the coefficients, including the interaction terms), the sign of the total effect (i.e., main effect and interaction effect) equals the main effect as presented in Table 5 . The only difference can be found in the coefficient of the number of locations and the average experience of teachers, which has a positive sign (so a negative interpretation) if interaction terms are included. From Table 5 we observe that 
Table 5

Estimation results control variables in the model.

\begin{tabular}{|c|c|c|c|c|}
\hline Variable & Estimate & Standard error & $T$-statistic & $P$-value \\
\hline Competition & -0.034 & 0.015 & -2.247 & {$[.025]$} \\
\hline Number of schools per governing body & 0.007 & 0.006 & 1.033 & {$[.302]$} \\
\hline Percentage students from disadvantaged neighborhood & 0.015 & 0.005 & 3.213 & {$[.001]$} \\
\hline Percentage urbanization & -0.010 & 0.009 & -1.124 & {$[.261]$} \\
\hline Number of locations per school & -0.036 & 0.116 & -0.311 & {$[.756]$} \\
\hline Years of experience teachers & -0.032 & 0.023 & -1.413 & {$[.158]$} \\
\hline Share part time teachers & 0.143 & 0.207 & 0.688 & {$[.492]$} \\
\hline
\end{tabular}

only two control variables have a significant direct influence on performance, namely competition and the share of disadvantaged students.

An increase in competition increases either student performance or costs. This is in line with previous literature (see for example Bradley, Johnes, \& Millington, 1999; Millimet \& Collier, 2008) and is intuitive as schools with more competition need to invest more in outperforming the other schools. Because of the competition, the incentive for excellence is higher, which in turn might lead to higher student performance. The negative relation between the share of students from a disadvantaged neighborhood and student performance is in line with the findings in the literature (e.g., Becker \& Luthar, 2002).

With respect to the insignificant findings which are confirmed by our analysis of the averages, we see that an increase in share of part time teachers either decreases student performance or decreases costs. This is in line with previous literature (e.g., Jacoby, 2006). The finding on urbanization is similar to previous literature. Naper (2010) shows that schools with many students from rural areas tend to be less efficient, indicating the importance of including both the degree of urbanization and a region variable.

\section{Conclusion and discussion}

This paper studies the optimal allocation of resources in secondary education. We use a semi-parametric efficiency model with budget constraints, in particular the budget restricted indirect Fourier output distance function, to estimate both technical and allocative efficiency scores for 448 Dutch secondary schools between 2002 and 2007. Tests for the parametric specification of the output distance function indicate that the Fourier function of grade 1 is to be preferred. Four types of resources are distinguished: management, teachers, supporting personnel and material use. With the given resources, schools are supposed to maximize student performance as proxied by central examination grades. We control for heterogeneity among schools by including control variables, e.g., information on the share of students from disadvantaged neighborhoods.

The results indicate that the average technical efficiency score for the 448 schools amounts to $78 \%$, implying that with the same resources schools could improve educational performance by about $28 \%$. Moreover, we observe an overutilization of teachers by $0.65 \%$ (which is about 400 FTE (Ministry of Education, 2011b)) and an underutilization of other personnel resources in 2007. The absolute numbers of our results are not that different from the predictions made by CentER data, ECORYS and QQQ Delft (2006), who predicted a teacher shortage of about 1000 FTE in 2007 on a total of about 62,000 teachers. In contrast to previous findings which computed only an overall number, this paper made a clear distinction between the various employee types and argues what type of staff schools are using too much or too little. This additional information is extremely useful to policymakers.

Our findings imply that a different allocation of resources is not necessary for most schools, and that the national teacher shortage cannot be solved or reduced by the reallocation of resources. However, more than 25 percent of the schools have (far) too many teachers, compared with the optimum and for these schools reallocation of their surplus teachers to the shortage schools could be a solution to the teacher shortage.

Second, the results yield information on the characteristics of schools with respect to overall performance. Performance is higher if there are a higher percentage of students from disadvantages neighbourhoods, more schools per governing body and more part time teachers. The latter two correlations are not statistically significant. Overutilization is modest in urban areas and in schools with a higher number of locations, although the latter two correlations are not significantly different from zero.

From an intertemporal perspective and in contrast to previous findings, the results indicate that between 2002 and 2004 there was an overutilization of teachers. In those years, a better allocation of teachers between schools could have decreased the teacher shortage for the bottom quartile of schools. Despite the significant heterogeneity across schools, this article argues that efficiency gains are possible in some secondary schools by reallocating resources.

\section{Acknowledgements}

We would like to thank Wim Groot, Henriëtte Maassen van den Brink, TIER-seminar participants and EWEPA 2011 participants for useful comments. The usual caveat applies.

\section{Appendix A. Productivity model}

To estimate productive efficiency, we estimate an output distance function and a number of cost share equations. The functional form of the production function has been 
estimated as a Fourier function of grade 1 . The model is algebraically presented as:

$$
\begin{aligned}
\ln (\mathrm{IOD})= & a_{0}+\sum_{i=1}^{m} b_{i} \ln \left(Y_{i}\right)+\sum_{i=1}^{n} c_{i} \ln \left(\frac{W_{i}}{C}\right)+\sum_{i=1}^{n^{\prime}} d_{i} \ln \left(Z_{i}\right) \\
& +\frac{1}{2} \sum_{i=1}^{m} \sum_{j=1}^{m} b_{i j} \ln \left(Y_{i}\right) \ln \left(Y_{j}\right)+\frac{1}{2} \sum_{i=1}^{n} \sum_{j=1}^{n} c_{i j} \ln \left(\frac{W_{i}}{C}\right) \ln \left(\frac{W_{j}}{C}\right) \\
& +\frac{1}{2} \sum_{i=1}^{n^{\prime}} \sum_{j=1}^{n^{\prime}} d_{i j} \ln \left(Z_{i}\right) \ln \left(Z_{j}\right)+\sum_{i=1}^{m} \sum_{j=1}^{n} e_{i j} \ln \left(Y_{i}\right) \ln \left(\frac{W_{j}}{C}\right) \\
& +\sum_{i=1}^{n^{\prime}} \sum_{j=1}^{n} f_{i j} \ln \left(Z_{i}\right) \ln \left(\frac{W_{j}}{C}\right)+\sum_{i=1}^{n^{\prime}} \sum_{j=1}^{m} g_{i j} \ln \left(Z_{i}\right) \ln \left(Y_{j}\right) \\
& +\sum_{i=1}^{N} \lambda_{1 i} * \sin \left(\ln \left(\frac{W_{i}}{C}\right)\right)+\sum_{i=1}^{N} \lambda_{2 i} * \cos \left(\ln \left(\frac{W_{i}}{C}\right)\right) \\
& +\sum_{i=1}^{N} \lambda_{3 i} * \sin \left(\ln \left(Y_{i}\right)\right)+\sum_{i=1}^{N} \lambda_{4 i} * \cos \left(\ln \left(Y_{i}\right)\right) \\
& +\sum_{i=1}^{N} \lambda_{5 i} * \sin \left(\ln \left(Z_{i}\right)\right)+\sum_{i=1}^{N} \lambda_{6 i} * \cos \left(\ln \left(Z_{i}\right)\right) F E+\mu
\end{aligned}
$$

where IOD = indirect output distance function; $C=$ total costs; $Y_{i}=$ output/production-indicator $i(i=1, \ldots, m)$; $W_{i}=$ price used resource $i(i=1, \ldots, n) ; Z_{i}=$ environmental variable $i\left(i=1, \ldots, n^{\prime}\right) ; F E=$ fixed effects on school type, year and region; $\mu=$ randomly distributed error term $a_{0}, b_{i}, c_{i}$, $d_{i}, b_{i j}, c_{i j}, d_{i j}, e_{i j}, f_{i j}, g_{i}, \lambda_{1 i}, \lambda_{2 i}, \lambda_{3 i}, \lambda_{4 i}, \lambda_{5 i}$ and $\lambda_{6 i}$ are the estimated parameters.

Roy's identity is used to derive the optimal cost shares (see Färe \& Primont, 1995, p. 92). The optimal cost shares are the following:

$S_{i}^{o}=\left\{\frac{T_{i}}{\sum_{j=1}^{n} T_{j}}\right\}$

With

$$
\begin{aligned}
T_{i}= & c_{i}+\sum_{j=1}^{n} c_{i j} \ln \left(\frac{W_{j}}{C}\right)+\sum_{j=1}^{m} e_{i j} \ln \left(Y_{j}\right)+\sum_{j=1}^{n^{\prime}} f_{i j} \ln \left(Z_{j}\right) \\
& +\lambda_{1 i}\left(\cos \left(\frac{W_{i}}{C}\right)\right)-\lambda_{2 i}\left(\sin \left(\frac{W_{i}}{C}\right)\right) \\
& +\lambda_{11 i}\left(\cos \left(\frac{W_{i}}{C}\right)\right)-\lambda_{12 i}\left(\sin \left(\frac{W_{i}}{C}\right)\right)+\varepsilon
\end{aligned}
$$

The output distance function is specified as the Fourier grade 1 function and the share equations are derived from it. Homogeneity of degree one in prices and symmetry is imposed by putting constraints on some of the parameters to be estimated. These constraints are the following: $\sum_{i=1}^{n} b_{i}=1, \sum_{i=i}^{n} b_{i j}=0, \forall j$ and $\sum_{i=i}^{n} e_{i j}=0, \forall j$.

\section{Appendix B. Supplementary data}

Supplementary data associated with this article can be found, in the online version, at doi:10.1016/ j.econedurev.2012.02.007.

\section{References}

Abbott, M., \& Doucouliagos, C. (2009). Competition and efficiency: Overseas students and technical efficiency in Australian and New Zealand Universities. Education Economics, 17(1), 31-57.

Aigner, D. J., Lovell, C. A., \& Schmidt, P. (1977). Formulation and estimation of stochastic frontier production function models. The Journal of Econometrics, 6(1), 21-37.

Ball, C. G., \& Goldman, S. (1997). Improving education's productivity: Reexamining the stystem to get the schools we need. Phi Delta Kappan, 78(3), 228-232

Banker, R. D., Janakiraman, S., \& Natarajan, R. (2004). Analysis of trends in technical and allocative efficiency: An application to Texas public school districts. European Journal of Operational Research, 154, 477-491.

Becker, B. E., \& Luthar, S. S. (2002). Social-emotional factors affecting achievement outcomes among disadvantaged students: Closing the achievement gap. Educational Psychologist, 37(4), 197-214.

Blank, J. L. (2009). Non-maximizing output behavior for firms with a costconstrained technology. Journal of productivity analysis, 31(1), 27-32.

Blank, J. L. T. (2010). Principes van productiviteitsmeting. Elementaire handleiding voor kwantitatief onderzoek naar de productiviteit, doelmatigheid, effectiviteit en kwaliteit van de publieke sector. Maastricht: Shaker Publishing B.V.

Blank, J. L. T., Koot, P. M., \& van Hulst, B. L. (2007). Overhead of Onderwijs - Een benchmark van de allocatie van middelen in onderwijsinstellingen voor voortgezet onderwijs. Delft/Rotterdam: IPSE Studies/ECORYS.

Blatchford, P., \& Sumpner, C. (1998). What do we know about breaktime? Results from a national survey of breaktime and lunchtime in primary and secondary schools. British Educational Research Journal, 24(1), 79-94.

Bradley, S., Johnes, G., \& Millington, J. (1999). School choice, competition and the efficiency of secondary schools in England. Lancaster University Management School Working Paper 003. 
Cazals, C., Florens, J. P., \& Simar, L. (2002). Nonparametric Frontier estimation: A robust approach. Journal of Econometrics, 106(1), 1-25.

CentER data/ECORYS/QQQ Delft (2006). De toekomstige arbeidsmarkt voor onderwijspersoneel tot 2015. Den Haag: Ministerie van Onderwijs, Cultuur en Wetenschap.

Chalfant, J. A., \& Gallant, A. R. (1985). Estimating substitution elasticities with the Fourier cost function. Journal of Econometrics, 28, 205-222.

Charnes, A., Cooper, W., \& Rhodes, E. (1978). Measuring the efficiency of decision making units. European Journal of Operational Research, 2(6), 429-444.

Cherchye, L., \& Vanden Abeele, P. (2005). On research efficiency. A microanalysis of Dutch university research in Economics and Business Management. Research Policy, 34, 495-516.

Coelli, T. J., Rao, D. S. P., O’Donnell, C. J., \& Battese, G. E. (2005). An introduction to efficiency and productivity analysis (2nd ed.). New York: Springer.

Cooley Nichols, S. M., Bicard, S. C., Bicard, D. F., \& Casey, L. B. (2008). A field at risk: The teacher shortage in special education. Phi Delta Kappan, 89(8), 597-600.

European Commission. (2006). Progress towards the Lisbon objectives in education and training. Brussels: European Commission.

Executive Agency of Education Audiovisual and Culture. (2009a). National summary sheets on educational system in Europe and ongoing reforms The Netherlands. Brussels: European Commission.

Executive Agency of Education Audiovisual and Culture. (2009b). Organisation of the education system in the Netherlands. Brussels: European Commission.

Färe, R., \& Primont, D. (1995). Multi-output production and duality: Theory and applications. Dordrecht: Kluwer Academic Publishers.

Fried, H. O., Lovell, C. A. K., \& Schmidt, S. S. (2008). The measurement of productive efficiency and productivity growth. New York: Oxford University Press.

Gallant, A. R. (1981). On the bias in flexible functional forms and an essentially unbiased form - The Fourier flexible form. Journal of Econometrics, 15, 211-245.

Gallant, A. R. (1984). The Fourier flexible form. American Journal of Agricultural Economics, 66(2), 204-208.

Greene, W. H. (2008). Econometric analysis. New Jersey: Prentice-Hall International.

Groom, B., \& Rose, R. (2005). Supporting the inclusion of pupils with social, emotional and behaviourial difficulties in the primary school: The role of teaching assistants. Journal of Research in Special Educational Needs, 5(1), 20-30.

Grosskopf, S., Hayes, K. J., Taylor, L. L., \& Weber, W. L. (1997). Budgetconstrained Frontier measures of fiscal equality and efficiency in schooling. Review of Economics and Statistics, 79(1), 116-124.

Grosskopf, S., Hayes, K. J., Taylor, L. L., \& Weber, W. L. (2001). On the determinants of school district efficiency: Competition and monitoring. Journal of Urban Economics, 49(3), 453-478.

Hargreaves, L., Cunningham, M., Everton, T., Hansen, A., Hopper, B., McIntyre, D., et al. (2006). The status of teachers and the teaching profession: Views from inside and outside the profession (Interim findings from the teacher status report). Department for Education and Skills.

Hargreaves, L., Cunningham, M., Hansen, A., McIntyre, D., Oliver, C., \& Pell, T. (2007). The status of teachers and the teaching profession: Views from inside and outside the profession (Final report of the teacher status report). Department for Education and Skills.

Ingersoll, R. M., \& Perda, D. (2010). Is the supply of mathematics and science teachers sufficient? American Educational Research Journal, 47(3), 563-594.

Inspectie van het Onderwijs. (2011). De staat van het onderwijs - Onderwijsverslag 2009/2010. Utrecht: Inspectie van het Onderwijs.

Jacoby, D. (2006). Effects of part-time faculty employment on community college graduates rates. The Journal of Higher Education, 77(6), 1081-1103.
Johnes, G., \& Johnes, J. (2009). Higher education institutions' costs and efficiency: Taking the decomposition a further step. Economics of Education Review, 28, 107-113.

King, N. (2009). Drastic shortage of teachers feared in Germany. Deutsche Welle.

Kuenzle, M. (2005). Cost efficiency in network industries: Application of stochastic frontier analysis. Swiss Federal Institute of Technology: Zurich.

Kumbhakar, S. C., \& Lovell, C. A. K. (2003). Stochastic Frontier Analysis. Cambridge University Press.

Lipsett, A. (2008). Teacher shortage in key subjects feared. The Guardian.

Mangrubang, F. R. (2005). Issues and trends in science education: The shortage of qualified science teachers. American Annals of the Deaf, $150(1), 42-46$

Meeusen, W., \& Van den Broeck, J. (1977). Efficiency estimation from Cobb-Douglas production functions with composed error. International Economic Review, 18(2), 435-444.

Millimet, D. L., \& Collier, T. (2008). Efficiency in public schools: Does competition matter? Journal of Econometrics, 145, 134-157.

Ministry of Education. (2005). Nota werken in het onderwijs 2006. Den Haag.

Ministry of Education (2011a). Retrieved from: www.functiemix. minocw.nl.

Ministry of Education (2011b). Kerncijfers 2006-2010. Den Haag: Ministry of Education, Culture and Science.

Ministry of Education (2011c). Nota werken in het onderwijs 2011. Den Haag: Ministry of Education, Science and Culture.

Municipality of Amsterdam (2003). Convenant personeelstekort in het Amsterdams onderwijs. Amsterdam: Sectorbestuur Onderwijsarbeidsmarkt.

Naper, L. R. (2010). Teaching hiring practices and educational efficiency. Economics of Education Review, 29, 658-668.

Nelis, H. (2004). Leerlingen geven oplossingen voor het lerarentekort. $V V$ Magazine, 4, 10-11.

Odenthal, L., Poelmann, M., van der Ven, A., \& van der Weide, J. (2007). De kloof tussen management en docenten. Amersfoort: CPS.

Rothstein, J. (2010). Teacher quality in educational production: Tracking, decay, and student achievement. The Quarterly Journal of Economics, 125(1), 175-214.

Santiago, P. (2002). Teacher demand and supply: Improving teacher quality and addressing teacher shortages. OECD.

Sectorbestuur Onderwijsarbeidsmarkt (2009). Tekort schoolleiders in het primair onderwijs. Den Haag: SBO.

Simkins, T. (2000). Education reform and managerialism: Comparing the experience of schools and colleges. Journal of Education Policy, 15(3), 317-332.

Soares de Mello, J. C. C. B., Goncalves Gomes, E., Angulo Meza, L., Soares de Mello, M. H. C., \& Soares de Mello, A. J. R. (2006). Engineering postgraduate programmes: A quality and productivity analysis. Studies in Educational Evaluation, 32, 136-152.

Stb., 1963;40. Wet op het voortgezet onderwijs, Stb., 1963. 40. Laatste wijziging Stb. 2010. 80.

Stijnen, P. J. J. (2003). Leraar worden: 'under construction'? Open University Netherlands, Heerlen.

Tauer, L. W., Fried, H. O., \& Fry, W. E. (2007). Measuring efficiencies of academic departments within a college. Education Economics, 15(4), 473-489.

Van Velden, W. (2002). Schoolleiders gezocht. VV Magazine, 1, 8-9.

Wenger, J. W. (2000). What do schools produce? Implications of multiple outputs in education. Contemporary Economic Policy, 18(1), 27-36.

Yatchew, A. (1998). Nonparametric regression techniques in economics. Journal of Economic Literature, 36, 669-721. 